\title{
Islamic Economics, Banking and Finance
}

\author{
Bashir Al-Zu'bi
}

The fifth intensive orientation course under the title "Islamic Economics, Banking and Finance" was held in Markfield, U.K., September 25-28, 1997.

The course was organized by the Islamic Development U.K., in cooperation with the Islamic Development Bank, Jeddah, Saudi Arabia, and Loughborough University, Loughborough, U.K. More than 100 guest speakers, organizers, and participants attended.

The participants were very active in panel discussions. The topics included Islamic banking and finance, Islamic economics, economic development from the Islamic perspective, the creation of money, the rationale of prohibiting interest and its prohibition in westem literature, debt, equity, Islamic fund management, the role of zakat in the eradication of poverty, Islamic finance in the West, and the new halal investment company in Europe. 
As a starting point, Dr. Umer Chapra presented a paper on the present state of Islamic economics. He emphasized the importance of economics in explaining the fall of Muslim power. He also pointed out the effect of Islamic values and institutions, including zakat and the abolition of interest. He added that now it is time to solve the practical problems that the Muslim countries are facing and also to show ways of realizing the Islamic vision of a society where development is taking place with justice.

Dr. Monawar Iqbal talked about the rationale of Islamic banking and the services that people are in need of, e.g., investment in the form of mudarabah, musharakah, and murabah.

Attention was paid to the following features of Islamic banking: risk sharing, productivity as compared to credit worthiness, moral dimension, equity, efficiency, stability, and growth.

The experience of Islamic banking in Pakistan, Iran, and Sudan was discussed. In addition, there was a discussion on multinational entities (e.g., Islamic Development Bank). Dr. Iqbal emphasized the major problems facing Islamic banking such as lack of profit sharing on the asset side, adverse selection, moral hazard, lack of project appraisal machinery, lack of project monitering, defaulters and the issue of penalties, illogicality of the Islamic financial market, short-term asset structure, excess liquidity, short-term placement of funds, lack of a lender of last resort, difficulties in issuing letters of guarantee, and taxation.

Despite these problems, 192 Islamic banks were operating by the end of 1996. An analysis of 166 of these banks was made by Dr. Samir Shaikh, who described their current profile and showed that their net profit in 1996 was $\$ 1,683,648$. On the suggestion of Dr. Tarigullah Khan the principles of Islamic finance were grouped into the following categories: benevolence, sharing principle, deferred sale-principle, and sharing-cum-deferred sale.

The course also included lectures on the Muslim decline in the nineteenth and twentieth centuries.

Dr. Umar Chapra used Ibn Khaldun's model with its six elements: justice, development, wealth, government, the institutions and organizations, and the end as well as the means. He pointed out that Islam is not the cause of decline; rather, decline is caused by political illegitimacy, conspicuous consumption and corruption, reduced savings and investment, lowered development. He raised the question of what is to be done for revival. His answer is to go back to education and social uplift, to social service, to peaceful and democratic struggle for political change, and to a policy of nonconfrontation.

The course included discussion of the prohibition of interest in western literature. Dr. John Presley mentioned that Islam doesn't have a monopoly on advocating the prohibition of interest. He added that while 
contemporary economist literature sets interest at the center of its economic system, historically, philosophers and various religious denominations (but not economists) have set themselves against interest for religious, moral, theoretical, and practical considerations, including macroeconomic stability.

The concept of economic development from the Islamic perspective was discussed by Dr. Khurshid Ahmad, who formulated the following general goals of development for a Muslim society: (a) human resource development; (b) expansion of useful production; (c) improvement of the quality of life; (d) balanced development; (e) new technology; and (f) reduction of national dependency on the outside world and greater integration within the Muslim world.

Monetary policy according to Islam was introduced by Dr. Ausaf Ahmad. Monetary policy is considered an important instrument to finetune a modern economy. The speaker addressed (a) the role of the Central Bank in Islamic economy, (b) the objectives of monetary policy in an Islamic economy, and (c) instruments of monetary policy in an Islamic economy (i.e., quantitative and prudential measures).

New suggested instruments include (a) profit sharing ratio, (b) reliance ratio, (c) public share of demand deposits, (d) value oriented allocation of credit, (e) Qarl hasan ratio, and (f) maximum and minimum make-up ratio.

Dr. Ahmad elaborated on monetary policy in Iran, Pakistan, and Sudan. Dr. Rodney Wilson posed the question: Can we manage an Islamic fund? emphasized that Islamic investors should not regard overall equity capital as a substitute for mudarabah or musharakah, as the characteristics are different

We expected stock markets to grow substantially in the coming years through the Islamic world. In order to gain a full understanding of Islamic banking, we should consider the challenge of the twenty-first century.

Dr. Khurshid Ahmad said that the year 1975 can rightly be described as the watershed for the global stage. He added that the phenomenon of Islamic banking is one of the major innovations introduced in the last quarter of the twentieth century. He pointed out that the most important challenge relates to the future of the world economy toward declining income, wealth, and opportunity, adversely affecting around one-third of mankind.

The speaker suggested that the fundamental principles expounded by Islam are destined to play a crucial role in reconstructing the economy in the twenty-first century on very sound foundations.

Mr. Dato Ahmad Abdul Rahman, speaking about his experience of Islamic banking in Malaysia, mentioned that Islamic debt and equity finance have developed in the world; existing infrastructure statistics 
show that the proportion of Islamic deposits and finance remained small; and strategies are designed to increase the market share of Islamic financial institutions 5 percent by the year 2000 .

Dr. Glenn Stewart presented the practical experience gained from the new halal mutual investment company in Europe developed over the last three years by Al-Tadamaon Company Ltd. The goals of the fund are preserving capital, producing regular recurrent income based on the Islamic shari'ah, and providing a reasonable degree of liquidity for those people who would like to get their capital back on short notice.

The speaker believes strongly that the best way to structure Islamic financial products for Muslims living in western countries is either on a mudarabah or a musharakah basis.

Dr. Jone Collada Medina presented a paper on the creation of money according to Ibn Rushd. Creation of money isn't a recent or modern process. The idea of the stability of currency is a fundamental contribution of Ibn Rushd. He asserted that one function of money is that it is a measure of value, and this value cannot be variable. Zakat has a significant role in solving social as well as economic problems. One of these is the eradication of poverty.

Dr. Abdel Hamid Brahimi emphasized that zakat resources will not be sufficient to meet all the needs of people, so we need to look for other financial resources that can be generated through the undertaking of economic reforms with the following objectives:

1. The new fiscal system should express social justice in conformity with Islamic teachings.

2. The new fiscal measures should constitute a means of encouraging the private and public productive activities to be in a position of self-financing the expansion of their activities by creating new jobs and thus contributing to economic growth.

3. Some measures will be taken to ensure the simplification of taxes and the transparency of all operations in the fiscal field.

4. The use of modern technology, the appropriate training of staff, and the modernization of management of taxes constitute a precious means of transparency and efficiency.

5. The budgetary expenses of fiscal origin should serve some objectives of ranked priorities of general interest, such as the eradication of poverty, which is an absolute priority.

Zakat and the implementation of the above fiscal reform could jointly have a considerable socioeconomic impact an the economy, especially if accompanied by a reform of the financial system.

In conclusion, the course was successful and fruitful. I hope in the coming years that concentration will be placed upon the practical aspects of the Islamic banking system. 